\title{
Experimental Organism Benign Thymoma Neoplasm
}

National Cancer Institute

\section{Source}

National Cancer Institute. Experimental Organism Benign Thymoma Neoplasm. NCI

Thesaurus. Code C114115.

A benign neoplasm of the thymus, originating from epithelial thymus cells. 